\title{
Aging-related premature luteinization of granulosa cells is avoided by early oocyte retrieval
}

\author{
Yan-Guang $\mathrm{Wu}^{1}$, David H Barad ${ }^{1,2,3}$, Vitaly A Kushnir ${ }^{1,4}$, Emanuela Lazzaroni', \\ Qi Wang', David F Albertini, ${ }^{1,5}$ and Norbert Gleicher ${ }^{1,2,6}$ \\ ${ }^{1}$ The Center for Human Reproduction (CHR), 21 East 69th Street, New York, New York 10021, USA \\ ${ }^{2}$ Foundation for Reproductive Medicine, New York, New York 10021, USA \\ ${ }^{3}$ Department of Obstetrics and Gynecology, Albert Einstein College of Medicine, Bronx, New York 10461, USA \\ ${ }^{4}$ Department of Obstetrics and Gynecology, Wake Forest University, Winston Salem, North Carolina 27106, USA \\ ${ }^{5}$ Department of Molecular and Integrative Physiology, University of Kansas Medical Center, Kansas City, \\ Kansas 66160, USA \\ ${ }^{6}$ Stem Cell Biology and Molecular Embryology Laboratory, The Rockefeller University, New York, \\ New York 10065, USA
}

\author{
Correspondence \\ should be addressed \\ to $\mathrm{Y}-\mathrm{G}$ Wu \\ Email \\ ywu@thechr.com
}

\begin{abstract}
Why IVF pregnancy rates decline sharply after age 43 is unknown. In this study, we compared granulosa cell (GC) function in young oocyte donors $(n=31$, ages 21-29), middle-aged ( $n=64$, ages 30-37) and older infertile patients ( $n=41$, ages 43-47). Gene expressions related to gonadotropin activity, steroidogenesis, apoptosis and luteinization were examined by real-time PCR and western blot in GCs collected from follicular fluid. FSH receptor (FSHR), aromatase (CYP19A1) and 17 $\beta$-hydroxysteroid dehydrogenase (HSD17B) expression were found down regulated with advancing age, while LH receptor (LHCGR), P450scC (CYP11A1) and progesterone receptor $(P G R)$ were up regulated. Upon in vitro culture, GCs were found to exhibit lower proliferation and increased apoptosis with aging. While FSH supplementation stimulated GCs growth and prevented luteinization in vitro. These observations demonstrate age-related functional declines in GCs, consistent with premature luteinization. To avoid premature luteinization in women above age 43 , we advanced oocyte retrieval by administering human chorionic gonadotropin at maximal leading follicle size of $16 \mathrm{~mm}$ (routine 19-21 mm). Compared to normal cycles in women of similar age, earlier retrieved patients demonstrated only a marginal increase in oocyte prematurity, yet exhibited improved embryo numbers as well as quality and respectable clinical pregnancy rates. Premature follicular luteinization appears to contribute to rapidly declining IVF pregnancy chances after age 43 , and can be avoided by earlier oocyte retrieval.
\end{abstract}
Key Words
- premature luteinization
- granulosa cell
- oocyte
- in vitro fertilization
- early retrieval

Journal of Endocrinology (2015) 226, 167-180

\section{Introduction}

Effects of female reproductive aging on assisted reproductive technologies are widely acknowledged. Age-related gradual declines in implantation and pregnancy rates (van Noord-Zaadstra et al. 1991) as well as increases in spontaneous miscarriages (Belloc et al. 2008, Grande et al. 2012) were observed. Declines in oocyte quantity and quality are considered principal driving forces through as yet ill-defined mechanisms (Navot et al. 1991). 
Based on annual reports to the Centers for Disease Control and Prevention (CDC), as required under a federal statute from IVF centers in the United States, our center is distinguished from most in serving the oldest IVF patient population. CDC reports further establish that with respect to the oldest age group of patients seeking infertility treatments ( $>43$ years), for which almost no national data are available, our center is unique in accommodating a disproportionate number of patients of advanced age.

While our center's IVF outcomes are reflective of the gradual decline in pregnancy rates normally observed with advancing female age, we have noted that this decline after age 43 sharply increases. Mechanisms leading to accelerated loss of ovarian function are unknown undoubtedly, however, related to the poor reproductive performance in women above age 43 .

Accordingly, we hypothesized that fast decreasing IVF pregnancy rates in older patients reflect poor ovarian environments, which adversely impacts oocyte/embryo quality and IVF outcomes (5). Specifically, we predicted that changes in immediate ovaria environments of oocytes, represented by granulosa cells (GCs), should be identifiable by comparing cell function at different maternal ages. Rapid declines in IVF pregnancy rates after age 43 may, therefore, reflect age-related functional decline in ovarian cells. These changes in the ovarian environment should be discoverable by comparing GC function.

Oocytes in primordial follicles remain arrested in meiotic prophase I until recruited for oogenesis. Oocytes and accompanying GCs engage and maintain a symbiotic relationship (Buccione et al. 1990). GCs form the follicular microenvironment, which facilitates oocyte development, supplies energy, disposes of waste and participates in molecular signaling. If GC function becomes impaired with advancing age, oocyte growth and competence will be compromised in parallel. For example, GCs synthesize and transport energy substrates, nucleotides and amino acids into oocytes (Buccione et al. 1990).

Using an in vitro oocyte growth model, Schultz et al. demonstrated that oocyte growth positively correlated with the number of adherent cumulus cells (CCs, representing more differentiated GCs) and the extent of metabolic cooperation between them (Brower \& Schultz 1982, Herlands \& Schultz 1984). Transcription in oocytes depends on the presence of attached CCs (De La Fuente \& Eppig 2001). In addition, the maintenance of oocyte arrest before recruitment also relies on the contribution of autocrine and paracrine factors synthesized in GCs, including cAMP/cGMP (Webb et al. 2002, Wigglesworth et al. 2013, Shuhaibar et al. 2015), purine (Downs 1993), kit ligand (Ye et al. 2009), and NPR2 (Zhang et al. 2010, Tsuji et al. 2012, Wigglesworth et al. 2013). Oocytes from antral follicles resume and complete meiosis spontaneously after removal of surrounding CCs (Buccione et al. 1990, Mehlmann 2005), suggesting that CCs control oocyte nuclear maturation.

Cytoplasmic maturation of oocytes also depends on CCs and GCs. Cumulus-oocyte complexes can mature and support embryo development after in vitro maturation (IVM). Removal of CCs before culture, resulting in denuded oocytes (DOs), leads to impaired oocyte and embryo development (Buccione et al. 1990). One striking example of metabolic cooperation between oocytes and surrounding CCs pertains to glutathione synthesis. Because glutathione derived from GCs and CCs is required for sperm decondensation and male pronucleus formation, lack of ability to produce glutathione in DOs restrains their development (Perreault et al. 1988, Zhou et al. 2008, 2010). Hence, when DOs are co-cultured with GC monolayer during IVM, glutathione levels are restored and developmental competence is reestablished (Zhou et al. 2008, 2010). Normal growth and maturation of the oocyte is thus a direct reflection of physiological status of the GCs.

Certain defects of gene expression result in loss of GC function, which in turn can lead to reproductive dysfunctions. For example, follicle stimulating hormone receptor (Fshr) knockout in mouse GCs results in infertility due to lack of antral follicles (Dierich et al. 1998). Similarly, knockout of aromatase (Cyp19a1) (Fisher et al. 1998), IGF1 (Baker et al. 1996), estrogen receptor $\beta$ (Esr2) (Couse et al. 2005) and androgen receptor (Ar) (Sen \& Hammes 2010) in GCs leads to premature ovarian aging (POA) and female subfertility/infertility. To further prove the importance of GCs, Seifer and Sadraie reported significantly higher percentages of apoptotic GCs in infertile women, diagnosed with low functional ovarian reserve (Seifer et al. 1996, Sadraie et al. 2000). Other investigators reported diminished proliferation (Seifer et al. 1993), and high levels of mitochondrial DNA deletions (Seifer et al. 2002) in GCs of aged IVF patients. All of these abnormalities in GCs have the potential of contributing to decreased reproductive success in older women.

Our study, therefore, reports on functional attributes of GCs derived from three groups of women: young oocyte donors (Group 1), middle-aged infertile women (Group 2) and old infertile women above age 43 (Group 3). As we demonstrate, in Group 3, a significant decline in GC

Published by Bioscientifica Ltd. 
function is detected that exhibits characteristics of premature luteinization. Based on these findings, we also report on results of a clinical pilot study of early oocyte retrieval in Group 3, which appear to ameliorate the negative impact of premature luteinization. This discovery provides insights into ovarian aging, and offers alternative strategies for improving pregnancy chances in older women.

\section{Materials and methods}

\section{Patient populations and institutional review board}

The Institutional Review Board of the Center for Human Reproduction (CHR) approved this study in expedited review.

Based on age, three distinct age groups were investigated (Table 1): oocyte donors represented the youngest (Group $1 ; n=31$ ). By definition, they are young and carefully selected, meeting age-specific ovarian reserve parameters. Group 2 represented young to middle-aged infertility patients within an age range of 28-38 years $(n=64)$ while Group 3 included the oldest infertility patients at $43-47$ years $(n=41)$.

Patient and IVF cycle characteristics are shown in Table 1. All subjects underwent controlled ovarian hyperstimulation and oocyte maturation by human chorionic gonadotropin (hCG) according to previously described protocols (Gleicher \& Barad 2011, Gleicher et al. 2013), followed by transvaginal ultrasound-guided oocyte retrieval. hCG was administered when leading follicles reached 19-21 mm. Oocyte donors were stimulated in a long gonadotropin releasing hormone agonist cycle (GnRHa, Lupron, leuprolide acetate, Takeda Pharmaceutical USA, Inc., Deerfield, IL, USA) with daily dosages of 150-300 IU of human menopausal gonadotropin (hMG) from various manufacturers. In contrast, infertility patients were stimulated in microdose agonist cycles (Lupron) with daily dosages of 450-600 IU of gonadotropins, typically in a majority (300-450 IU) administered as FSH, and in a minority (150 IU) as hMG.

Follicular fluid was collected at time of oocyte retrieval only from follicles $15 \mathrm{~mm}$ or larger.

\section{Oocyte/embryo assessment and fertilization}

All media and reagents for IVF were purchased from LifeGlobal (Guilford, CT, USA). Oocytes collected at retrievals were cultured in HTF medium containing 10\% human serum albumin (HSA) for $2 \mathrm{~h}$ before insemination. After removal of cumulus by hyaluronidase treatment, oocytes were assessed according to morphology. Oocytes with obvious first polar body (1st $\mathrm{Pb}$ ) were identified as mature (MII); oocytes without 1 st $\mathrm{Pb}$ were identified as immature (MI \& GV); oocytes with brown dark color, cytoplasmic fragments and/or broken membranes were identified as atretic. Only MII oocytes were used for insemination.

Fertilized embryos were cultured in vitro in Blastocyst medium (LifeGlobal) for 3 days, then were assessed according to their morphology. Embryos with 4-12 blastomeres of equal size and minimal cytoplasmic fragmentation were identified as good embryos, and designated as suitable for transfer or cryopreservation.

\section{Hormone measurement}

All serum hormone concentrations of patients were examined with AIA 900 Automated Immunoassay Analyzer (Tosoh, Minato, Japan) by following the instruction of user manual except AMH. Basic concentrations of FSH and

Table 1 Patient populations and cycle characteristics

\begin{tabular}{|c|c|c|c|}
\hline & $\begin{array}{c}\text { Group } 1 \\
\text { Donors }(n=31)\end{array}$ & $\begin{array}{c}\text { Group } 2 \\
\text { Intermediate age infertility } \\
\text { patients }(n=64)\end{array}$ & $\begin{array}{c}\text { Group } 3 \\
\text { Older infertility patients } \\
(n=41)\end{array}$ \\
\hline Average age (years) & $24.4 \pm 0.52^{a}$ & $34.1 \pm 0.38^{b}$ & $44.3 \pm 0.23^{c}$ \\
\hline $\mathrm{FSH}(\mathrm{mlU} / \mathrm{ml})$ & $6.3 \pm 0.23^{a}$ & $7.6 \pm 0.57^{a}$ & $10.3 \pm 0.34^{b}$ \\
\hline $\mathrm{AMH}(\mathrm{ng} / \mathrm{ml})$ & $3.1 \pm 0.23^{a}$ & $2.8 \pm 0.26^{a}$ & $0.28 \pm 0.08^{b}$ \\
\hline Number of follicles/cycle & $22.5 \pm 8.3^{a}$ & $10.5 \pm 7.1^{\mathrm{b}}$ & $6.8 \pm 5.1^{c}$ \\
\hline Number of oocytes retrieved/cycle & $20.6 \pm 1.2^{a}$ & $9.8 \pm 2.5^{b}$ & $5.2 \pm 1.3^{c}$ \\
\hline Number of MII oocytes retrieved/cycle & $15.5 \pm 5.2^{\mathrm{a}}$ & $7.1 \pm 2.3^{b}$ & $3.6 \pm 0.8^{c}$ \\
\hline Number of artretic oocytes retrieved/cycle & $1.3 \pm 0.4^{a}$ & $0.9 \pm 0.2^{\mathrm{ab}}$ & $0.6 \pm 0.1^{\mathrm{b}}$ \\
\hline Number of embryo $\geq 4$ cells & $15.5 \pm 4.6^{\mathrm{a}}$ & $7.1 \pm 0.89^{b}$ & $3.6 \pm 20^{c}$ \\
\hline Pregnant rate/cycle & $16(\overline{1} 1.6 \%)^{a}$ & $22(34.4 \%)^{b}$ & $3(7.3 \%)^{c}$ \\
\hline Progesterone/estradiol ratio & $0.26 \pm 0.08^{a}$ & $0.5 \pm 0.15^{b}$ & $1.96 \pm 0.47^{c}$ \\
\hline
\end{tabular}

Values with same letters in their superscripts in same row were not different significantly $(P>0.05)$. $n$, number of patients.

http://joe.endocrinology-journals.org DOI: $10.1530 / \mathrm{JOE}-15-0246$
(C) 2015 Society for Endocrinology Printed in Great Britain
Published by Bioscientifica Ltd. 
AMH were determined on day 2 or day 3 of menstrual cycle. Progesterone $\left(\mathrm{P}_{4}\right)$ and estradiol $\left(\mathrm{E}_{2}\right)$ were measured on the hCG administration day. Regarding the user manual and installment instruction from the technique supports, coefficient of variation $(\mathrm{CV})$ was performed by running one sample 20 times, then was calculated using the following equation: $\mathrm{CV}=$ (s.D.) (100)/mean. The results were analyzed by Tosoh technique support and listed as follows: $\mathrm{CV}(\mathrm{FSH})=1.1 \% ; \mathrm{CV}\left(\mathrm{E}_{2}\right)=2.1 ; \mathrm{CV}\left(\mathrm{P}_{4}\right)=2.2$. All $\mathrm{CV}$ values were verified as normal by Tosoh. The $\mathrm{P}_{4} / \mathrm{E}_{2}$ ratio was calculated as $\mathrm{P}_{4}$ (in $\left.\mathrm{ng} / \mathrm{ml}\right) \times 1000 / \mathrm{E}_{2}$ (in $\mathrm{pg} / \mathrm{ml}$ ). Serum AMH was measured commercially (LabCorp., Ramsey, NJ, USA).

\section{GC isolation}

Following retrieval, clumps of GCs were removed from follicular fluid. To avoid blood contamination, collected GCs were washed twice in D-PBS (Zenith Biotech, Guilford, CT, USA) by centrifugation ( $326 \mathrm{~g}, 5 \mathrm{~min})$, and following PBS removal GCs pellets were either frozen at $-80^{\circ}$ for future use or prepared for in vitro culture.

\section{RNA extraction and real-time PCR}

Total RNA was extracted using TRIzol-reagent (Invitrogen) and $1 \mu \mathrm{g}$ of RNA was reverse transcribed using RT enzyme (Invitrogen). cDNA amplification and quantification of PCR products was done with the StepOne real-time PCR system (Applied Biosystems) according to the manufacturer's instructions using Sybr Green (Invitrogen). Standard PCR settings $\left(95^{\circ} \mathrm{C}\right.$ for $10 \mathrm{~min}$, and 40 cycles of $95^{\circ} \mathrm{C}$ for $15 \mathrm{~s}$ and $60^{\circ} \mathrm{C}$ for $1 \mathrm{~min}$, then dissociation stage for $15 \mathrm{~s}$ at $95^{\circ} \mathrm{C}, 1 \mathrm{~min}$ at $60^{\circ} \mathrm{C}, 15 \mathrm{~s}$ at $95^{\circ} \mathrm{C}$, and $15 \mathrm{~s}$ at $60^{\circ} \mathrm{C}$ ) were used. PCR primers and product information of all tested genes are listed in Supplementary Table 1, see section on supplementary data given at the end of this article. To avoid DNA contamination in PCR, primers pair must be separated by at least one intron (at least $5000 \mathrm{bp}$ ) and the corresponding genomic DNA. The specific PCR amplifications were validated by running melting curve analysis and gel analysis. The primers that have only one PCR product with correct size were chosen for the study. The efficiency of amplification was determined by running standard curve (efficiency of assay: 90-105\%; R2 > 0.98; all Cq values were similar). Each sample was run in duplicate. For each target gene, the number of mRNA molecules was calculated and expressed relative to ribosomal protein L19 (RPL19) reference mRNA. To compare and calculate results from different PCR running, the normalization was performed as follows: each PCR run included a reference cDNA sample as control, which was made by mixing ten different patients' GCs. The results from different PCR runs were calculated according to these reference samples and final average gene expressions were then analyzed statistically.

\section{Western blot analysis}

All antibodies were purchased from Santa Cruz. GCs were homogenized in Ripa buffer (Sigma), and protein was purified as described by instructions. Protein concentrations were determined by using the Pierce BCA protein kit (Thermo Fisher Scientific, Rockford, IL, USA). Gel runs separated $20 \mu \mathrm{g}$ of total protein and Ripa buffer was used as negative control. After electric transfer, membranes were blocked for $2 \mathrm{~h}$ with $5 \%$ nonfat dry milk. Then membranes were incubated overnight at $4{ }^{\circ} \mathrm{C}$ with anti-CYP19A1 (sc-130733, $50 \mathrm{kDa}$ ) (1:500), anti-FSHR (sc-13935, $75 \mathrm{kDa})$ (1:500), anti-LHCGR (sc-25828, $85 \mathrm{kDa})$ (1:250), anti-BCL2 (sc-492, $26 \mathrm{kDa}$ ) (1:500) or anti-ACTB (sc-47778, $34 \mathrm{kDa})$ (1:500) antibody. After wash, secondary antibodies, conjugated to HRP (sc-2004) (1:10 000) were incubated for $2 \mathrm{~h}$ with membranes. Protein bands were visualized by incubating the membranes with Immoblot (Millipore Corp., Billerica, MA, USA). The specific bands were recognized regarding the expected sizes on the blot. Band densities were determined and normalized against the beta actin (ACTB) signal using Image $J$ software (NIH, Bethesda, MD, USA).

\section{GC culture}

Isolated GCs were seeded into six-well plates (BD Bioscience, San Jose, CA, USA) at density of $10 \times 10^{5} / \mathrm{ml}$ in DMEM/F12 containing 10\% FBS, followed by incubation for $8 \mathrm{~h}$ at $37^{\circ}$ with $5 \% \mathrm{CO}_{2}$ to allow GC attachment. To remove cell debris and serum factors, cultures were washed twice and incubated in serum-free DMEM/F12, containing $2 \mathrm{mg} / \mathrm{ml}$ of HSA (LifeGlobal), $2 \mathrm{mM}$ glutamine (Life Technologies) and $1 \times$ Insulin-Transferin-Selenium $X$ (Life Technologies). After overnight culture, medium was replaced once more. GCs were cultured for 1,3 or 5 days, and medium was changed every $48 \mathrm{~h}$.

\section{Cell proliferation and apoptosis assays}

Cell proliferation analyses were performed by using Vybrant MTT Cell Proliferation Assay Kit (Life Technologies). Briefly, GCs were seeded at densities of

Published by Bioscientifica Ltd 
5000 cells/well in 96-well plates. Following a medium change, $10 \mu \mathrm{l}$ of $12 \mathrm{mM}$ MTT stock solution was added to each well and the plate was incubated at $37^{\circ} \mathrm{C}$ for $4 \mathrm{~h}$. Then $100 \mu \mathrm{l}$ of SDS- $\mathrm{HCl}$ was added, and following another $4 \mathrm{~h}$ of incubation absorbance of each well was read at $570 \mathrm{~nm}$, using a micro-plate reader (Tecan, Mannedorf, Switzerland). Apoptosis was determined in GCs plated at the density previously described in four-well chamber slides (Thermo Fisher Scientific). Cultured GCs were fixed by adding in $1 \mathrm{ml}$ D-PBS containing $4 \%$ paraformaldehyde for $15 \mathrm{~min}$. Slides were then labeled with $10 \mu \mathrm{g} / \mathrm{ml}$ 4,6-diamidino-2-phenylindole-2-HCL (DAPI) (Sigma) for $10 \mathrm{~min}$, and nuclear morphology was assessed using fluorescence microscopy. Apoptotic GCs, exhibiting distinct fragmented nuclei, were counted, and the apoptotic ratio was calculated for each treatment group based on number of apoptotic cells out of a total of 200 cells/slide.

\section{Pilot study of early oocyte retrieval}

Given the results of the previously described experiments, we hypothesized that the oldest patients (Group 3) might benefit clinically if their risk of premature luteinization could be curtailed or completely avoided. Therefore, we reasoned that development of premature luteinization could be pre-empted by scheduling oocyte retrieval earlier. We report here a preliminary summary of such an early retrieval group (ERG), that included 71 consecutive IVF cycles in women above age 43 (mean age $44.8 \pm 0.3$ years), for which cycle outcomes could be compared to a reference group of 91 women above age 43 , who in the preceding year had been treated with normal retrieval timing (NRG, mean age $44.3 \pm 0.15$ years).

The ERG received identical stimulation as previously described for the infertile patients (Groups 2 and 3) and, therefore, identical stimulation to the NRG control group. What distinguished these groups, however, was the timing of hCG administration. While NRG patients had been triggered with hCG at leading follicle size of $19-21 \mathrm{~mm}$, the ERG group was triggered at $16 \mathrm{~mm}$. Otherwise, IVF cycles were identical.

\section{Statistical analysis}

All statistical analyses were performed using Prism software (GraphPad Software, Inc., La Jolla, CA, USA). One-way ANOVA, followed by the Tukey test was used for the statistical analysis of real-time PCR, western blot, MTT assay and cell number calculations. Unpaired $t$-tests with
Welch's correction was used for statistical comparison of clinical data between ERG and NRG patients. The data in all tables and figures are shown as value \pm s.E.M. Values were considered statistically significant at $P<0.05$.

\section{Results}

\section{Patient populations and cycle characteristics}

Patient and IVF cycle characteristics are summarized in Table 1. Mean ages were $24.4 \pm 0.52$ years for Group 1, $34.1 \pm 0.38$ years Group 2 and $44.3 \pm 0.23$ years for Group 3. The table also demonstrates expected increases in FSH and decreases in AMH values with advancing age as well as declining oocyte/embryo numbers and pregnancy rates. Thus, Group 3 clearly reflected the lowest reproductive potential.

The table also reports serum $\mathrm{P}_{4}$ to $\mathrm{E}_{2}$ ratios $\left(\mathrm{P}_{4} / \mathrm{E}_{2}\right)$ in all three groups. The $\mathrm{P}_{4} / \mathrm{E}_{2}$ was significantly higher in Group 3, while there was no significant difference between Groups 1 and 2. An elevated $\mathrm{P}_{4} / \mathrm{E}_{2}$ is a well known marker of premature luteinization (Ozcakir et al. 2004) and, therefore, suggested that older patients might be at higher risk for premature luteinization than the other two groups.

\section{Impact of maternal aging on gene expression in human GCs}

To determine the impact of maternal aging, we quantified expressions of gonadotropin and sex hormone receptors in GCs. FSHR expression was significantly lower in Group 3 patients than Group 1 and Group 2 (Fig. 1A), while, in contrast, LH receptor (LHCGR) expression was significantly higher in Group 3 than Groups 1 and 2 (Fig. 1B). Expressions of estrogen receptor $\beta$ (ESR2) (Fig. 1C) and androgen receptor (AR) (Fig. 1D) did not differ between the three groups. Down-regulation of $F S H R$ and up-regulation of LHCGR mRNA levels in older patients were then confirmed by western blot (Fig. $2 \mathrm{~A}, \mathrm{C}$ and D).

To define the steroidogenic activity of GCs with advancing age, mRNA expression of steroidogenic enzymes was analyzed. Aromatase (CYP19A1) (Fig. 1E) and 17ß-HSD (HSD17B) (Fig. 1H) were expressed significantly lower in Group 3 women, while P450scc (CYP11A1) (Fig. 1F) was expressed higher. In contrast, expression of the steroidogenic acute regulatory protein (StAR) was similar in all three groups (Fig. 1G). Interestingly, despite small patient numbers, CYP19A1 expression in donors (Group 1) was higher than in both infertility

Published by Bioscientifica Ltd 


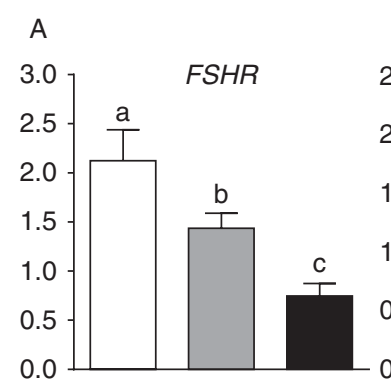

B $\quad$ C

C $\quad$ D

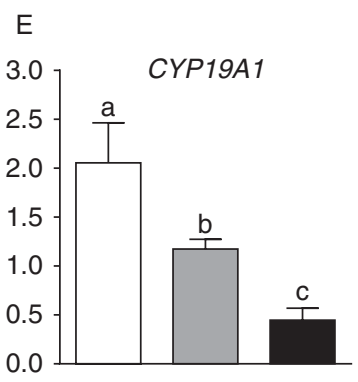

$\mathrm{F}$
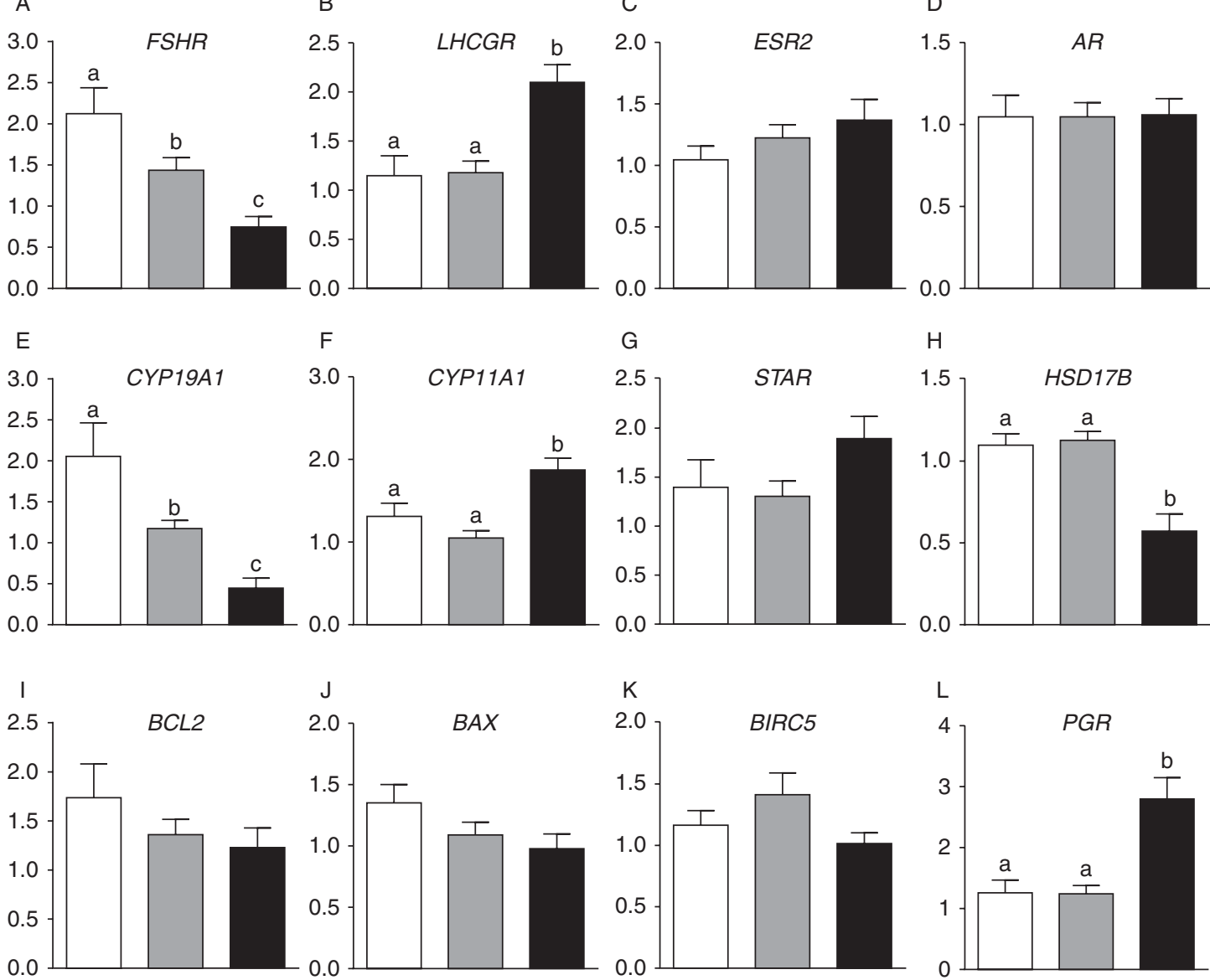

Figure 1

mRNA expression of GC genes was determined by real-time PCR. Values with same letters or without letters above the columns within each unit figure were not different significantly $(P>0.05)$. White columns: Group 1

groups (Group 2 and Group 3, $P<0.05$ ), a finding confirmed then by western blot (Fig. 2A and B).

Because apoptosis is generally increased in older women (Seifer et al. 1996, Sadraie et al. 2000), we also investigated expressions of apoptosis-related genes in GCs (Fig. 1I, J and K). We found no differences in expression of B-cell lymphoma 2 (BCL2), bcl-2-associated X protein $(B A X)$ and survivin (BIRC5) in all groups. These PCR results were then confirmed by western blot (Fig. 2A and E).

Combined with increased $L H C G R$ expression, reduced FSHR and CYP19A1 expression in older infertile women further suggests that their GCs undergo earlier luteinization. To obtain further evidence, we also measured expression of progesterone receptor $(P G R)$, another GC differentiation marker. Q-PCR results demonstrated that GCs from older women (Group 3) expressed higher $P G R$ than the other groups (Fig. 1L). Luteinization of (oocyte donors), $n=7$; Grey columns: Group 2 (middle-aged infertile patients), $n=10$; Black columns: Group 3 (older infertile patients), $n=10$.

GCs, therefore, appears to happen earlier and faster in older women.

\section{Impact of maternal aging on proliferation and apoptosis of GCs during in vitro culture}

To investigate the effect of maternal aging on GC proliferation, we cultured GCs of all three groups in vitro with or without FSH. As Fig. 3A demonstrates, in absence of FSH, cell proliferation between days 1-5 of GCs in Groups 1 and 2 did not change, while in Group 3 patients proliferation declined fast, and to an extremely low level. Distinctively different growing patterns are apparent in Fig. 3C.

Even though we did not observe changed apoptosisrelated gene expression in freshly obtained GCs (Fig. 1), we still considered the possibility that the poor cell

Published by Bioscientifica Ltd. 
A
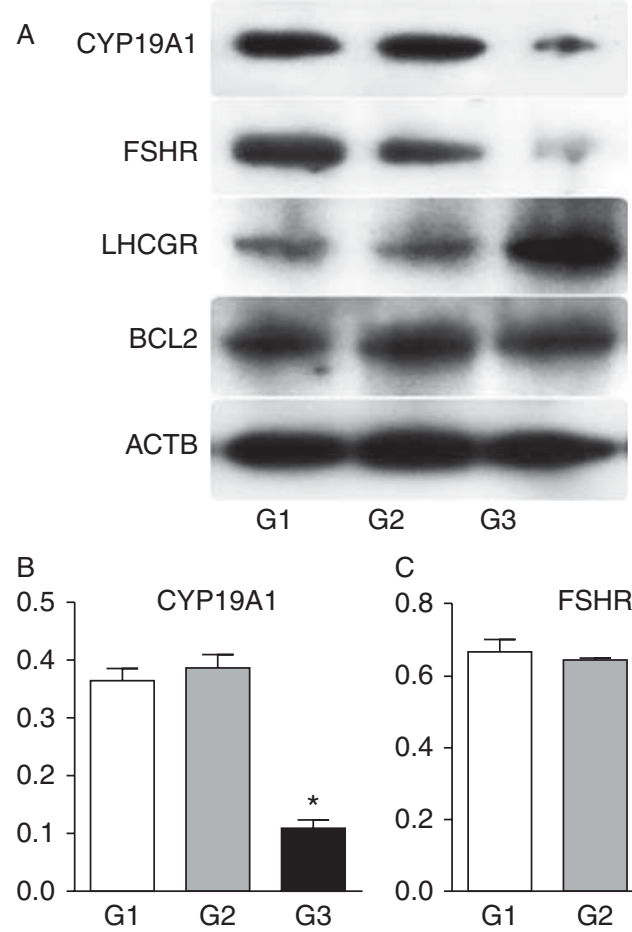

C
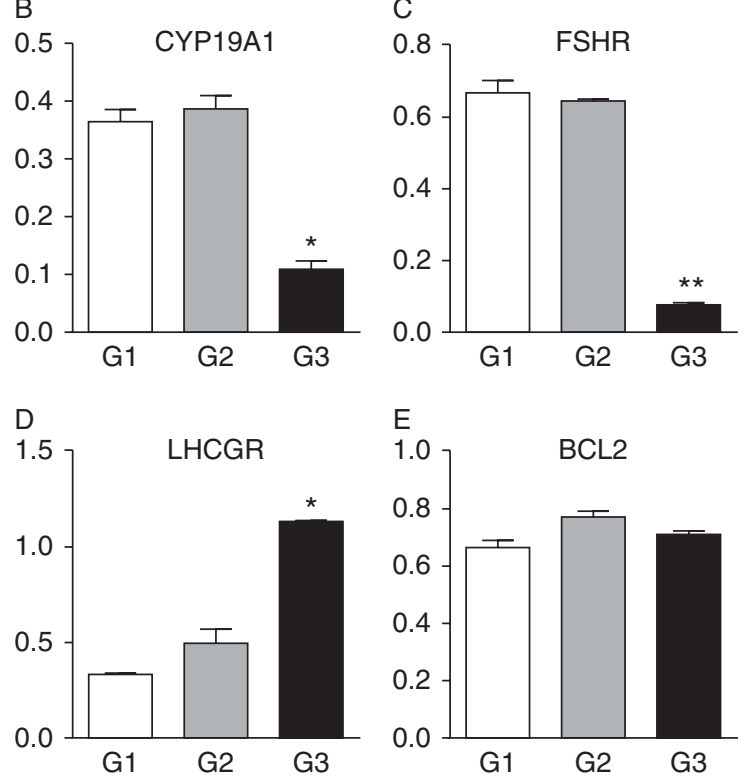

Figure 2

Protein expression of GC genes was determined by western blot. (A) Protein levels of aromatase, FHSR, LHR, BCL- 2 and $\beta$-actin were evaluated by western blot analysis. G1: Group 1; G2: Group 2; G3: Group 3; (B, C, D, and E) relative quantitative protein levels of aromatase (B), FHSR (C), LHCGR (D), $B C L 2$ (E) by western blot. The experiment was performed four times by using different samples of each age group. White columns: Group 1 (oocyte donors); grey columns: Group 2 (younger infertile patients); black columns: Group 3 (older infertile patients). ${ }^{*} P<0.05 ; * * P<0.01$.

proliferation we observed in cultured GCs in Group 3 may be caused by increasing apoptosis. As Fig. 3B demonstrates, apoptotic cells increased during culture in all three groups but the increase in apoptotic cells occurred much faster in Group 3. As suggested by others (Tapanainen et al. 1987, Langhout et al. 1991, Rouillier et al. 1998), our results also showed that FSH in all three groups demonstrated positive effects on proliferation and apoptosis of cultured GCs (Fig. 3A and B). In the presence of FSH, GCs from older patients, however, still demonstrate lower proliferation and higher apoptosis after culture.
Impact of maternal aging on gene expression of GCs during in vitro culture

To determine the effect of age on gene expression of cultured GCs, expression of FSHR, LHCGR, CYP19A1 and $B C L 2$ were investigated by Q-PCR and western blot. As shown in Fig. 4A and C, during culture FSHR and CYP19A1 mRNA expression increased in Groups 1 and 2, but not in Group 3. Presence of FSH in medium enhanced this upregulated expression even in Group 3.

PCR results were then confirmed by protein level examination (Fig. 4E). As shown in Fig. 4B, LHCGR expression also increased during culture, though differently from FSHR in that the increase was much faster in Group 3 (Fig. 4B and E). BCL2 expression decreased in all three groups (Fig. 4D), though the fastest in Group 3, with BCL2 protein expression by western blot concurring with PCR results (Fig. 4E). FSH inhibited this decline, suggesting inhibition of apoptosis by FSH in concurrence with previously noted results in Fig. 3B.

As demonstrated in Fig. 3B, compared to other groups, we noted higher cell apoptosis in Group 3 after culture in presence of FSH, which did not concur with the observed BCL2 expression in Fig. 4D and E. We, therefore, investigated in addition expressions of two other molecular markers for apoptosis, $B A X$ and BIRC5 by real-time PCR (Supplementary Figure 1, see section on supplementary data given at the end of this article). Since we did not find differences in expression of both of these genes, jointly with our BCL2 findings, this suggests that, though FSH apparently can regulate expression of apoptosis-related genes, it cannot completely reverse apoptosis.

\section{Effects of early oocyte retrieval in women of very advanced age ( $>43$ years)}

A preliminary assessment of early hCG administration in women of advanced age is presented in Table 2. As the table demonstrates, in comparison to 91 historical control cycles in women of very advanced age, who were retrieved with standard timing (the normal retrieval group, NRG), 71 women in this ERG were actually older $(44.8 \pm 0.3$ vs $44.3 \pm 0.15$ years; $P=0.001$ ); Their atretic oocytes were significantly reduced $(0.31 \pm 0.07$ vs $0.78 \pm 0.14, P=0.02)$. Immature oocytes were significantly increased $(1.98 \pm 0.98$ vs $1.1 \pm 0.17 ; P=0.01$ ) but good quality embryos per cycle still significantly increased $(3.6 \pm 0.36$ vs $2.8 \pm 0.24$; $P=0.04$ ). Moreover, clear trends in favor of the ERG were also seen in clinical pregnancy rate per cycle start, clinical pregnancy rate per embryo transfer and in embryo

Published by Bioscientifica Ltd. 
A

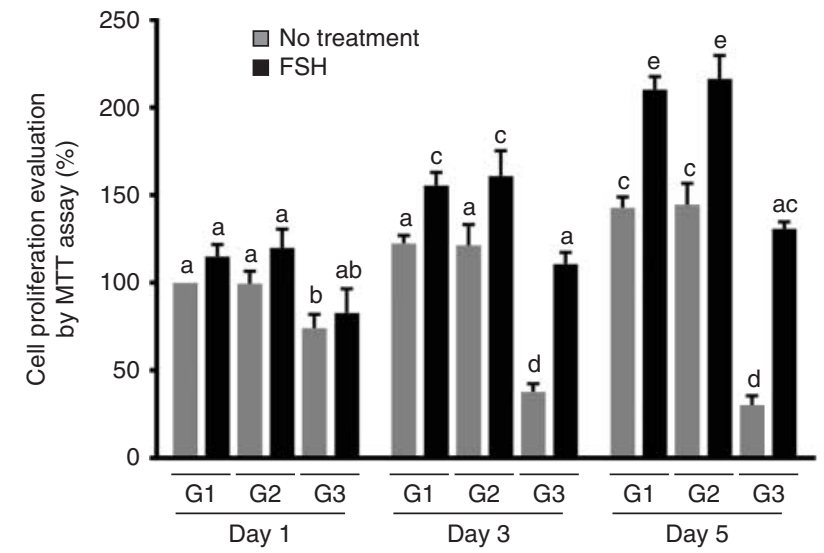

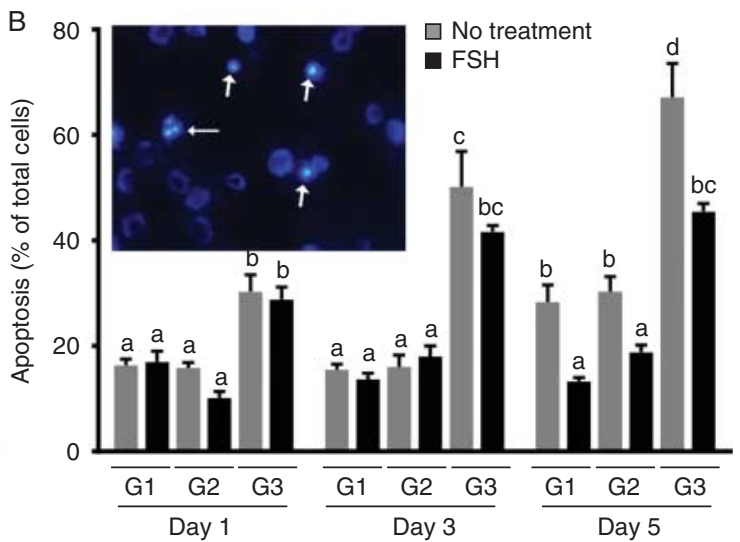

C

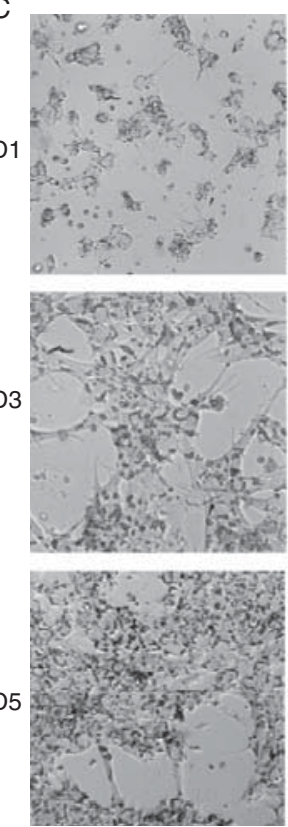

G1
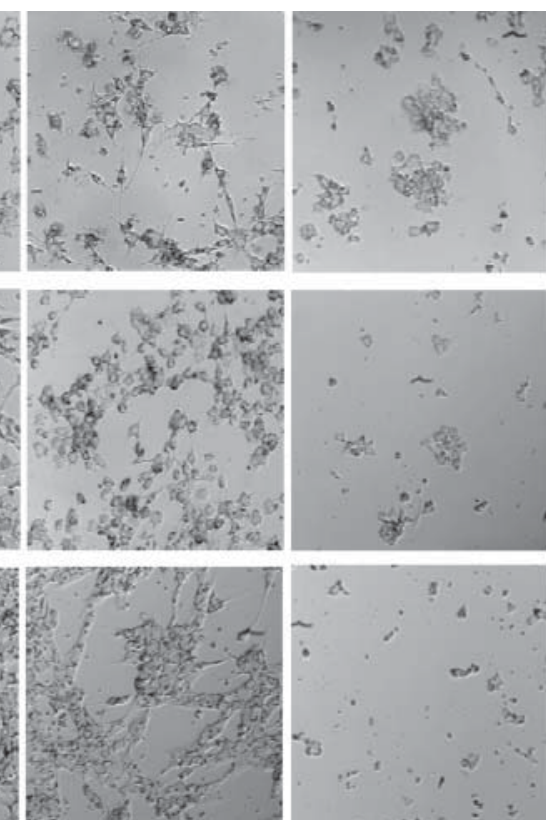

G3
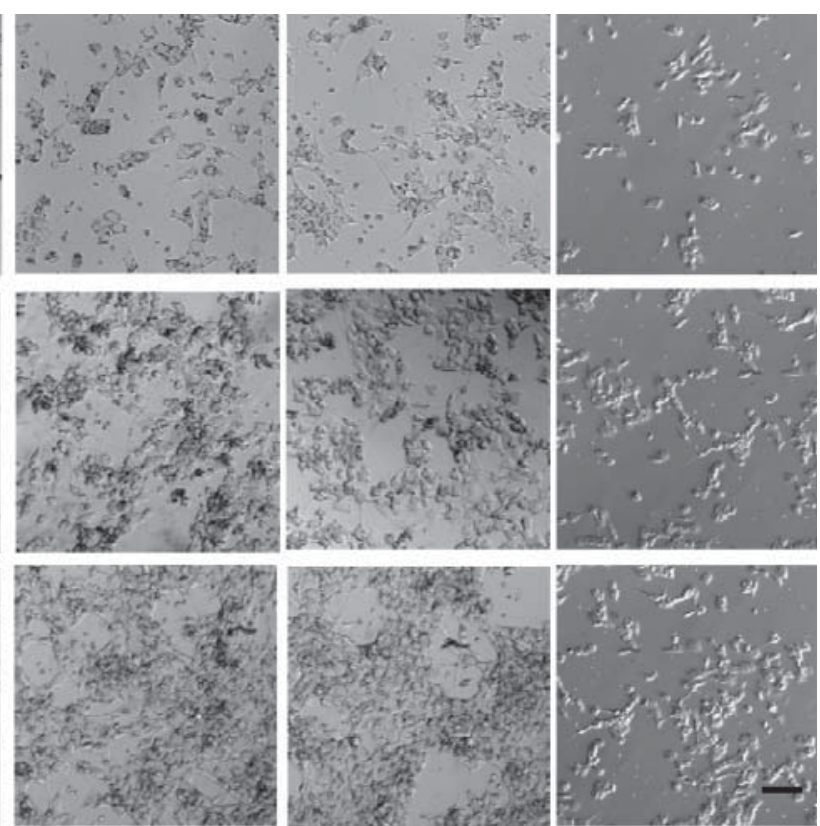

G1

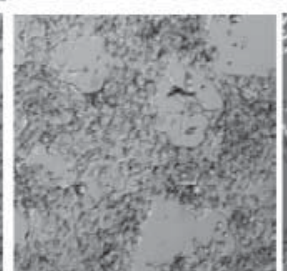

G2

$\mathrm{FSH}$

No treatment

\section{Figure 3}

GC proliferation was determined by MTT assay. PI staining after cell culture determined GC apoptosis. (A) Cell proliferation assay was performed after 1-5 days culture. GCs were collected from three different patients in each group and cultured separately. (B) PI staining after 1-5 days culture evaluated GC apoptosis. (C) Distinctively different growing patterns of cultured GCs on days 1-5, with and without FSH supplementation, are apparent in all three age groups. GCs were collected from three different

implantation rate, though so far limited patient numbers did not offer the statistical power to reach statistical significance.

The table, however, also demonstrates that early retrievals significantly decreased $\mathrm{P}_{4} / \mathrm{E}_{2}$ ratios in the ERG in comparison to the NRG ( $1.46 \pm 0.16$ vs $1.94 \pm 0.12$, $P=0.002$ ). Additionally, Fig. 5 presents gene expression studies, including 12 ERG, 12 NRG and six donor women, patients in each age group. In the inserted photograph in B, arrows indicate apoptotic cells after PI staining. Values with common letters above the columns within each unit figure were not different significantly $(P>0.05)$. G1: Group 1 (oocyte donors); G2: Group 2 (younger infertile patients); G3: Group 3 (older infertile patients). D1-5: day 1-5 of cell culture; $\operatorname{Bar}=20 \mu \mathrm{m}$.

demonstrating significant improvements in LHCGR, PGR and CYP19A1 expression of ERG patients, while FSHR expression was not affected significantly $(P>0.05)$ by early retrievals.

These preliminary data suggested that early ovulation induction in women of very advanced age demonstrates no adverse outcome effects on IVF, improves a number of well-established outcome parameters of IVF and, likely,

Published by Bioscientifica Ltd. 

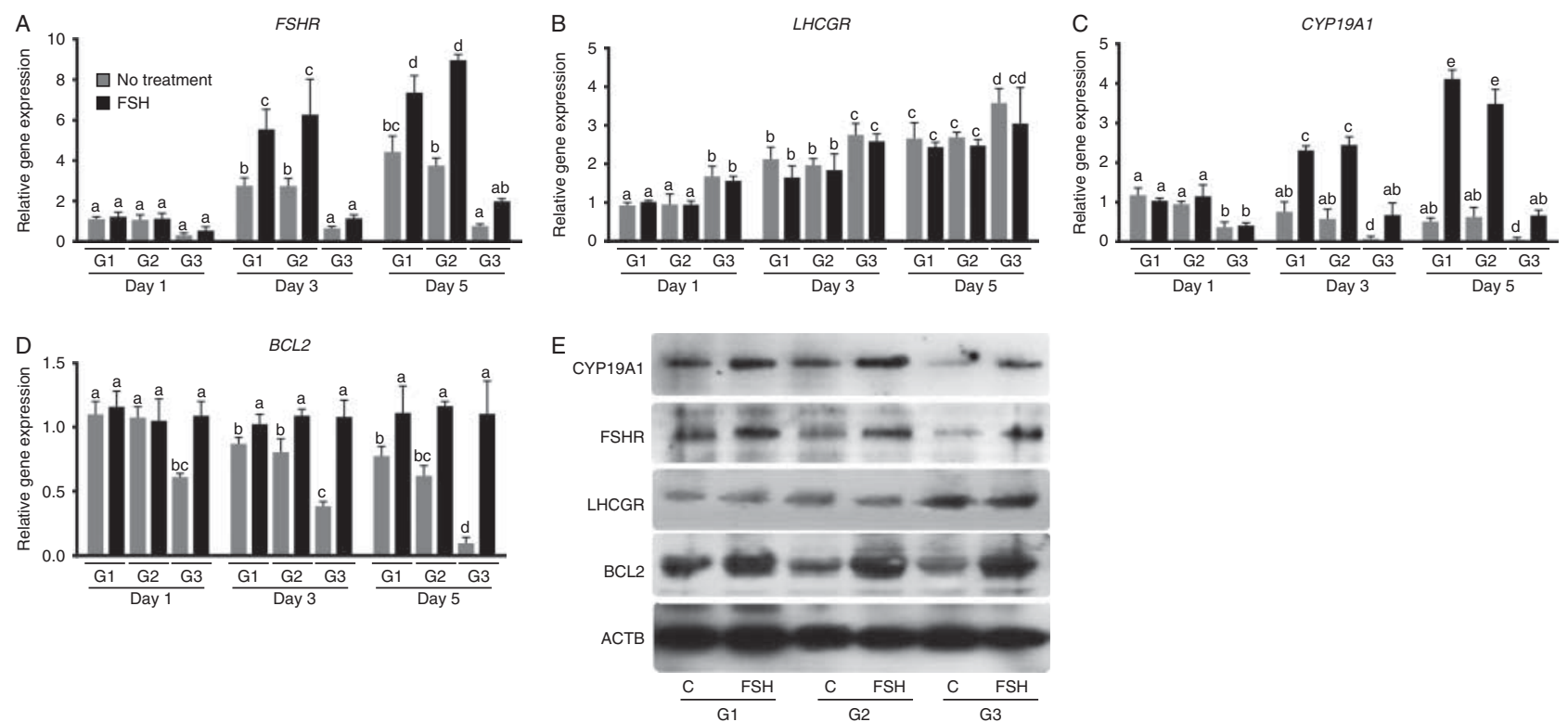

\section{Figure 4}

mRNA expression of GC genes was determined by real-time PCR ( $, B, C$, and $D)$. Protein expression was determined by western blot. GCs were collected from three different patients in each group and separately cultured. Values with common letters above the columns within each unit

ultimately may also improve clinical pregnancy rates in women above age 43 , though confirmation of the latter point awaits larger patient numbers.

\section{Discussion}

The decline of female fertility with advancing age is well documented (Tatone 2008, Tatone et al. 2008, Weeg et al. 2012, Younis 2012). It is usually attributed to declining oocyte numbers (Nasseri \& Grifo 1998, Out et al. 2000) and quality (Nasseri \& Grifo 1998, Slovis \& Check 2013). If the assumption of poorer oocyte quality is correct, then even figure did not differ significantly $(P>0.05)$. G1, Group 1 (oocyte donors); G2, Group 2 (younger infertile patients); G3, Group 3 (older infertile patients). C, control; FSH, follicle-stimulating hormone.

resting follicles and their enclosed oocytes should exhibit the detrimental consequences of 'aging'. We have questioned this 'oocentric' viewpoint on theoretical as well as practical grounds. Since primordial follicles are progenitor structures, widely held to have limited energy needs and metabolic activity, one could alternatively propose that their predisposition toward 'aging' is, likely, only minimal. Had they been subject to cumulative damage during natural aging, they only unlikely would have retained the ability to yield pregnancies and normal offspring. Even women of very advanced age and/or with very low functional ovarian reserve, if treated appropriately,

Table 2 Comparison of IVF cycle outcomes between ERG and NRG

Average age (years)

Number of follicles/cycle

Number of oocytes/cycle

Number of immature oocytes

Number of atretic oocytes from retrieval/cycle

Number of good embryos/cycle

Percentage of cycles resulting in pregnancies

Percentage of transferred cycles resulting in pregnancies

Implantation rate (\%)

Progesterone/estradiol ratio

ERG, early retrieval group; NRG, normal retrieval group. $n$, patient number.

\begin{tabular}{c} 
ERG $(n=71)$ \\
\hline $44.8 \pm 0.3$ \\
$7.2 \pm 0.58$ \\
$6.7 \pm 0.63$ \\
$1.98 \pm 0.29$ \\
$0.31 \pm 0.07$ \\
$3.6 \pm 0.36$ \\
$15.5(11 / 71)$ \\
$19.3(11 / 57)$ \\
5.3 \\
$1.46 \pm 0.16$ \\
\hline
\end{tabular}

\begin{tabular}{c}
\hline NRG $(n=91)$ \\
\hline $44.3 \pm 0.15$ \\
$7.3 \pm 0.56$ \\
$5.9 \pm 0.49$ \\
$1.1 \pm 0.17$ \\
$0.78 \pm 0.14$ \\
$2.7 \pm 0.24$ \\
$7.7(7 / 91)$ \\
$8.9(7 / 78)$ \\
3.3 \\
$1.94 \pm 0.12$ \\
\hline
\end{tabular}

\begin{tabular}{c}
\hline P value \\
\hline 0.001 \\
0.93 \\
0.31 \\
0.01 \\
0.02 \\
0.04 \\
0.14 \\
0.12 \\
0.34 \\
0.002 \\
\hline
\end{tabular}

\begin{tabular}{|lr}
\hline http://joe.endocrinology-journals.org & ○ 2015 Society for Endocrinology \\
DOI: $10.1530 / J O E-15-0246$ & Printed in Great Britain
\end{tabular}


CYP19A1

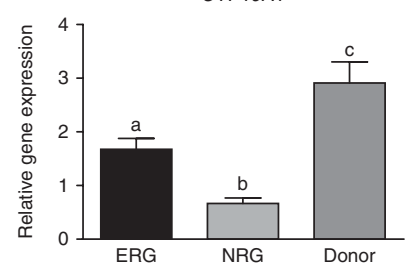

FSHR

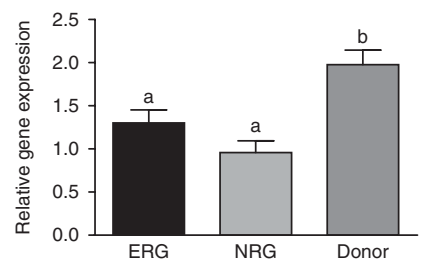

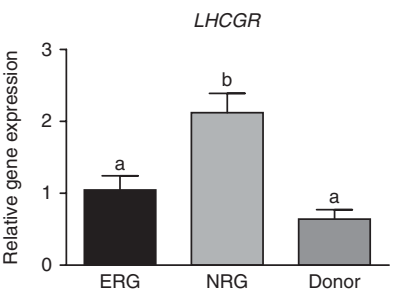

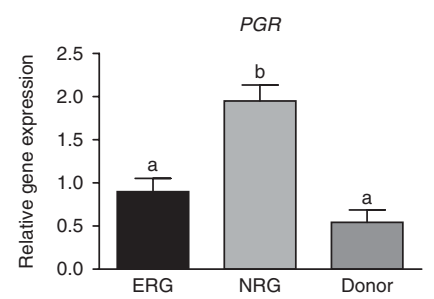

Figure 5

mRNA expression of GC genes was determined by real-time PCR. Values with common letters above the columns within each unit figure were not different significantly $(P>0.05)$. Black columns: older patients with early

however, still conceive and give birth to normal offspring. We, therefore, suggested that the concept of the 'aging oocyte' might have to be replaced by a concept of 'aging ovarian environments' in which follicles after recruitment undergo growth and maturation (Gleicher et al. 2011a). The difference between these two concepts is fundamental since likelihood of reversing intrinsic aging damage in an 'aged oocyte' is practically zero. If the culprit behind ovarian aging is, however, of somatic origin, therapeutic strategies directed towards reconstituting and/or rejuvenating 'aged ovarian environments', from which developmentally competent oocytes could be obtained, would offer promise for treatment of age-related infertility in older women.

This prospect is supported by androgen-related observations: older women exhibit relative low androgen levels (Gleicher et al. 2013). Moreover, androgens are known to be essential for normal follicle development during early growing follicle stages (Gleicher et al. 2011b). Indeed, androgen supplementation of the ovarian environment by raising testosterone levels improves egg/embryo numbers and quality as well as pregnancy rates (Gleicher \& Barad 2011), offering evidence for a novel approach toward therapeutically reversing to a degree selected effects of ovarian 'aging'.

Since GCs surrounding the oocyte define the immediate ovarian microenvironment, their critical role in supporting oocyte development might be the underlying target for endocrine perturbations associated with aging (Buccione et al. 1990). Although numerous studies have documented the relationship between poor oocyte quality and GC abnormalities in human and animals (Buccione et al. 1990, Senbon et al. 2003, Assou et al. 2012, Huang \& Wells 2012, Matsuda et al. 2012), effects of age on physiological function and molecular signature of GCs have so far been only sparsely investigated. Indeed, to our knowledge, they have never before been performed retrieval, $n=3$; light grey columns: older patients with normal retrieval $n=3$; dark grey columns: oocyte donor with normal retrieval (older infertile patients), $n=12$.

in such distinct age groupings (Hurwitz et al. 2010, McReynolds et al. 2012).

Our study comprehensively investigated the effects of ovarian aging in humans, and suggests that gene expression, proliferation, apoptosis and ability to respond to FSH stimulation in human GCs are all significantly affected by female age. Notably, Group 3 GCs demonstrated significantly increased LHCGR, PGR and CYP11A1 but reduced FSHR and CYP19A1 expression in comparison to other groups. Similar results have been observed in primates and other species. Luborsky et al. (2002) reported up-regulated $L H C G R$ expression in human luteinized GCs. Increased PGR (Natraj \& Richards 1993) and CYP11A1 (Rao et al. 1978) expression has been reported in rat luteinized GCs. Studies in humans and in the bovine suggest that LH surge-induced declines of FSHR represent the initiation of GC luteinization (Nimz et al. 2009, Jeppesen et al. 2012). Likewise, disappearance of CYP19A1 is another marker of luteinization in GCs (Campbell et al. 1998). Our results in older infertility patients (Group 3), therefore, closely parallel previously findings in, and suggest that premature luteinization of GCs is more likely to occur in older than in younger women.

High FSH initiates in natural cycles follicular development, leading to rising serum $\mathrm{E}_{2}$ concentrations by CYP19A1. This, in turn, causes a negative feedback on FSH release, and arrests the development of small growing follicles. High concentrations of $\mathrm{E}_{2}$ result in the preovulatory LH surge, which is responsible for final oocyte maturation and ovulation (Laven \& Fauser 2006). In here, reported IVF patients, FSH is, however, because of controlled ovarian hyperstimulation, maintained at higher levels. The consequence in some patients can be the triggering of a premature LH surge before follicles/ oocytes have fully matured, a phenomenon given the acronym 'premature luteinization' (60). Our results are, therefore, consistent with the fact that women above age

Published by Bioscientifica Ltd 
43 are at significantly increased risk to develop premature luteinization.

That premature luteinization negatively impacts oocyte quality, fertilization and implantation is supported by Skiadas et al. (2012) who demonstrated an association between low functional ovarian reserve in older women and premature luteinization, clinically characterized by higher peripheral LH and lower AMH levels. Also, oocyte numbers and top quality embryo numbers have been reported to be significantly higher in normal patients than in women with premature luteinization (Bosch et al. 2003, Elnashar 2010). In conjunction with here reported molecular data of older women, all of this points to premature luteinization as a principal cause in the agerelated decline of female fertility.

Higher exogenous FSH exposure may be a contributing factor to the increased risk toward premature luteinization (Elnashar 2010). Women with premature luteinization, indeed, may have higher day 3 FSH levels (Younis et al. 1998, 2001), though there are no data to support higher intracycle levels in the literature. In this study, FSH levels during ovarian hyperstimulation were not higher in Group 3 patients. Their elevated $\mathrm{P}_{4} / \mathrm{E}_{2}(>1)$ still suggests an increased risk for premature luteinization (Ozcakir et al. 2004).

In light of the widely held notion that physiological luteinization involves GC cell cycle exit and terminal differentiation, our results also suggest that premature luteinization may be linked to GC proliferation arrest and apoptosis. In support, Christenson \& Stouffer (1996) reported in primates and rats that an ovulatory luteinizing stimulus causes proliferation arrest and luteinization in cell differentiation (Rao et al. 1978, Oonk et al. 1989, Christenson \& Stouffer 1996), findings further supported by the down-regulation of cell cycle proteins, such as p2 $7^{\text {Kips }}$ and cyclin D2 (Fero et al. 1996, Cheng et al. 1999). In cancer cells, cell cycle regulators such as these are wellknown mediators, which initiate apoptosis in response to cell cycle arrest (Murphy 2000, Gutierrez et al. 1997). Whether a similar cell cycle checkpoint is operative in GCs of aged women remains to be determined but would be consistent with our observation that GCs of Group 3, indeed, demonstrated a higher level of apoptosis during culture (Fig. 3B).

Some caution is, nevertheless, warranted, especially in the presence of serum. GCs in culture spontaneously undergo structural and functional luteinization based upon changes in cell morphology, steroidogenesis and metabolism (Murphy 2000). Although GCs were cultured with serum-free medium here, it is impossible to completely prevent luteinization. FSH supplementation in medium can, inhibit GC luteinization in vitro, as demonstrated in the cow where GC morphology and estrogen production indicate maintenance of a preluteinized state (Gutierrez et al. 1997). Similar positive effects of FSH on GC growth and prevention of luteinization were also observed in human and rat (Lambert et al. 2000, Kwintkiewicz et al. 2010, Zhou et al. 2013).

The effects of FSH in this study are particularly noteworthy: it significantly enhanced cell proliferation (Fig. 3A and C), reduced apoptosis (Fig. 3B), and upregulated FSHR (Fig. 4A) and CYP19A1 (Fig. 4C) expression, suggesting at least partial inhibition of luteinization by FSH. Interestingly, although it caused significant improvements, GC function after FSH treatment was still far weaker in GCs of older women (Group 3), when compared to the other two groups, suggesting insufficient FSHR expression. Poor follicular response to FSH in older women is well recognized (Gleicher \& Barad 2006). Our observations heightens the significance, which provide compelling evidence that GCs of older women respond less effectively to FSH stimulation during in vitro culture, suggesting an underlying pathophysiology for declining female fertility.

Finally, our observation that FSH did not induce LHCGR expression in cultured GCs (Fig. 4B) requires further study because it is generally held that FSH induces LHCGR expression in vivo (Hirakawa et al. 1999, Orisaka et al. 2006, Cannon et al. 2009). A likely explanation for this result is that here investigated GCs were exposed to hCG in vivo. As shown by us and others (Murphy 2000, Hurwitz et al. 2010, Jeppesen et al. 2012, McReynolds et al. 2012), hCG administration causes luteinization of GCs, and a changing physiological and molecular signatures. Therefore, it is possible that hCG administration changes cell sensitivity of the FSH response. This hypothesis is supported by evidence from non-luteinizing GCs, where FSH activates the protein kinase A (PKA) pathway and then induces LHCGR transcription (Oury et al. 1992). But luteinization increases the stability of PKA subunit, which inhibited PKA activation by FSH (Gonzalez-Robayna et al. 1999). That the FSH/PKA-driven transcriptional protein, CREB, undergoes inhibitory phosphorylation in luteinized GCs (78), also supports this hypothesis.

Recognizing this pathophysiology in aged GCs then raised the question how such premature luteinization could be prevented. We hypothesized that the likelihood was early oocyte retrieval, which should release oocytes earlier from the hyper-luteinized follicular environments.

Published by Bioscientifica Ltd. 
Preliminary outcome analysis of 71 early retrieval IVF cycles in women above age 43, in comparison to 91 normal routine retrieval cycles, is highly encouraging (Table 2), though much larger patient numbers will be required to unequivocally demonstrate in this patient population that this new management scheme, ultimately, improves IVF pregnancy and delivery rates.

This study, however, with considerable certainty established non-inferiority for this new treatment and, with a reasonable level of likelihood suggest that early oocyte retrieval may improve IVF outcomes. The observation that earlier retrieval increased the number of high quality embryos available for transfer by reducing atretic oocyte numbers is reassuring because pregnancy and delivery success in IVF usually follows high quality embryo numbers. Optimism is also warranted since every outcome parameter, which did not significantly improve, without exception, strongly trended in favor of the ERG. It will take at least 150 IVF cycles in this patient population to reach adequate power for final statistical evidence that clinical pregnancy and live birth rates are, indeed, improved by a minimum of 20 percent.

In summary, we present here convincing in vivo and in vitro evidence that premature luteinization in infertile women of advanced age was associated with rapidly declining IVF pregnancy rates. We also present preliminary evidence, suggesting that, if such premature luteinization is avoided by earlier oocyte retrieval, IVF outcomes will be improved. Final confirmation of improved pregnancy and delivery outcomes will, however, require a larger patient pool than is available at time of this publication.

\section{Supplementary data}

This is linked to the online version of the paper at http://dx.doi.org/10.1530/ JOE-15-0246.

\section{Declaration of interest}

D H B and N G are listed as inventors on a number of US patents, among them, peripherally relevant to this study, patents claiming therapeutic benefits from androgen supplementation of women with LFOR. Both receive royalties from Fertility Nutraceuticals, LLC for licensing of some of these patents. N G holds shares in this company. None of the other authors report any potential conflicts in respect to the study.

\section{Funding}

This work was supported by the Foundation for Reproductive Medicine and intramural grants from the Center for Human Reproduction (CHR) New York.

\section{References}

Assou S, Haouzi D, De Vos J \& Hamamah S 2012 Human cumulus cells as biomarkers for embryo and pregnancy outcomes. Molecular Human Reproduction 16 531-538. (doi:10.1093/molehr/gaq032)

Baker J, Hardy MP, Zhou J, Bondy C, Lupu F, Bellve AR \& Efstratiadis A 1996 Effects of an Igf1 gene null mutation on mouse reproduction. Molecular Endocrinology 10 903-918. (doi:10.1210/mend.10.7.8813730)

Belloc S, Cohen-Bacrie P, Benkhalifa M, Cohen-Bacrie M, De Mouzon J, Hazout A \& Menezo Y 2008 Effect of maternal and paternal age on pregnancy and miscarriage rates after intrauterine insemination. Reproductive Biomedicine Online 17 392-397. (doi:10.1016/S14726483(10)60223-4)

Bosch E, Valencia I, Escudero E, Crespo J, Simon C, Remohi J \& Pellicer A 2003 Premature luteinization during gonadotropin-releasing hormone antagonist cycles and its relationship with in vitro fertilization outcome. Fertility and Sterility 80 1444-1449. (doi:10.1016/j.fertnstert. 2003.07.002)

Brower PT \& Schultz RM 1982 Intercellular communication between granulosa cells and mouse oocytes: existence and possible nutritional role during oocyte growth. Developmental Biology 90 144-153. (doi:10.1016/0012-1606(82)90219-6)

Buccione R, Schroeder AC \& Eppig JJ 1990 Interactions between somatic cells and germ cells throughout mammalian oogenesis. Biology of Reproduction 43 543-547. (doi:10.1095/biolreprod43.4.543)

Campbell BK, Baird DT \& Webb R 1998 Effects of dose of LH on androgen production and luteinization of ovine theca cells cultured in a serum-free system. Journal of Reproduction and Fertility 112 69-77. (doi:10.1530/jrf.0.1120069)

Cannon JD, Seekallu SV, Vandevoort CA \& Chaffin CL 2009 Association of luteinizing hormone receptor gene expression with cell cycle progression in granulosa cells. American Journal of Physiology. Endocrinology and Metabolism 296 E1392-E1399. (doi:10.1152/ajpendo.90965.2008)

Cheng M, Olivier P, Diehl JA, Fero M, Roussel MF, Roberts JM \& Sherr CJ 1999 The p21(Cip1) and p27(Kip1) CDK 'inhibitors' are essential activators of cyclin D-dependent kinases in murine fibroblasts. EMBO Journal 18 1571-1583. (doi:10.1093/emboj/18.6.1571)

Christenson LK \& Stouffer RL 1996 Proliferation of microvascular endothelial cells in the primate corpus luteum during the menstrual cycle and simulated early pregnancy. Endocrinology 137 367-374. (doi:10.1210/endo.137.8536637)

Couse JF, Yates MM, Deroo BJ \& Korach KS 2005 Estrogen receptor- $\beta$ is critical to granulosa cell differentiation and the ovulatory response to gonadotropins. Endocrinology 146 3247-3262. (doi:10.1210/en.20050213)

De La Fuente R \& Eppig JJ 2001 Transcriptional activity of the mouse oocyte genome: companion granulosa cells modulate transcription and chromatin remodeling. Developmental Biology 229 224-236. (doi:10.1006/dbio.2000.9947)

Dierich A, Sairam MR, Monaco L, Fimia GM, Gansmuller A, LeMeur M \& Sassone-Corsi P 1998 Impairing follicle-stimulating hormone (FSH) signaling in vivo: targeted disruption of the FSH receptor leads to aberrant gametogenesis and hormonal imbalance. PNAS 95 13612-13617. (doi:10.1073/pnas.95.23.13612)

Downs SM 1993 Purine control of mouse oocyte maturation: evidence that nonmetabolized hypoxanthine maintains meiotic arrest. Molecular Reproduction and Development 35 82-94. (doi:10.1002/mrd. 1080350114)

Elnashar AM 2010 Progesterone rise on the day of HCG administration (premature luteinization) in IVF: an overdue update. Journal of Assisted Reproduction and Genetics 27 149-155. (doi:10.1007/s10815010-9393-8)

Fero ML, Rivkin M, Tasch M, Porter P, Carow CE, Firpo E, Polyak K, Tsai LH, Broudy V, Perlmutter RM et al. 1996 A syndrome of multiorgan hyperplasia with features of gigantism, tumorigenesis, and female

Published by Bioscientifica Ltd 
sterility in p27(Kip1)-deficient mice. Cell 85 733-744. (doi:10.1016/ S0092-8674(00)81239-8)

Fisher CR, Graves KH, Parlow AF \& Simpson ER 1998 Characterization of mice deficient in aromatase (ArKO) because of targeted disruption of the cyp19 gene. PNAS 95 6965-6970. (doi:10.1073/pnas.95.12.6965)

Gleicher N \& Barad DH 2006 Effects of transdermal testosterone application on the ovarian response to FSH in poor responders undergoing assisted reproduction technique-a prospective, randomized, double-blind study. Human Reproduction 21 3027; author reply 3027-3028. (doi:10.1093/humrep/del302)

Gleicher N \& Barad DH 2011 Dehydroepiandrosterone (DHEA) supplementation in diminished ovarian reserve (DOR). Reproductive Biology and Endocrinology 9 67. (doi:10.1186/1477-7827-9-67)

Gleicher N, Weghofer A \& Barad DH 2011 $a$ Defining ovarian reserve to better understand ovarian aging. Reproductive Biology and Endocrinology 9 23. (doi:10.1186/1477-7827-9-23)

Gleicher N, Weghofer A \& Barad DH $2011 b$ The role of androgens in follicle maturation and ovulation induction: friend or foe of infertility treatment? Reproductive Biology and Endocrinology 9 116. (doi:10.1186/ 1477-7827-9-116)

Gleicher N, Kim A, Weghofer A, Kushnir VA, Shohat-Tal A, Lazzaroni E, Lee HJ \& Barad DH 2013 Hypoandrogenism in association with diminished functional ovarian reserve. Human Reproduction $\mathbf{2 8}$ 1084-1091. (doi:10.1093/humrep/det033)

Gonzalez-Robayna IJ, Alliston TN, Buse P, Firestone GL \& Richards JS 1999 Functional and subcellular changes in the A-kinase-signaling pathway: relation to aromatase and Sgk expression during the transition of granulosa cells to luteal cells. Molecular Endocrinology 13 1318-1337. (doi:10.1210/mend.13.8.0334)

Grande M, Borrell A, Garcia-Posada R, Borobio V, Munoz M, Creus M, Soler A, Sanchez A \& Balasch J 2012 The effect of maternal age on chromosomal anomaly rate and spectrum in recurrent miscarriage. Human Reproduction 27 3109-3117. (doi:10.1093/humrep/des251)

Gutierrez CG, Campbell BK \& Webb R 1997 Development of a long-term bovine granulosa cell culture system: induction and maintenance of estradiol production, response to follicle-stimulating hormone, and morphological characteristics. Biology of Reproduction 56 608-616. (doi:10.1095/biolreprod56.3.608)

Herlands RL \& Schultz RM 1984 Regulation of mouse oocyte growth: probable nutritional role for intercellular communication between follicle cells and oocytes in oocyte growth. Journal of Experimental Zoology 229 317-325. (doi:10.1002/jez.1402290217)

Hirakawa T, Minegishi T, Tano M, Kameda T, Kishi H, Ibuki Y, Mizutani T \& Miyamoto K 1999 Effect of prolactin on the expression of luteinizing hormone receptors during cell differentiation in cultured rat granulosa cells. Endocrinology 140 3444-3451. (doi:10.1210/endo.140.8.6888)

Huang Z \& Wells D 2012 The human oocyte and cumulus cells relationship: new insights from the cumulus cell transcriptome. Molecular Human Reproduction 16 715-725. (doi:10.1093/molehr/ gaq031)

Hurwitz JM, Jindal S, Greenseid K, Berger D, Brooks A, Santoro N \& Pal L 2010 Reproductive aging is associated with altered gene expression in human luteinized granulosa cells. Reproductive Sciences 17 56-67. (doi:10.1177/1933719109348028)

Jeppesen JV, Kristensen SG, Nielsen ME, Humaidan P, Dal Canto M, Fadini R, Schmidt KT, Ernst E \& Yding Andersen C 2012 LH-receptor gene expression in human granulosa and cumulus cells from antral and preovulatory follicles. Journal of Clinical Endocrinology and Metabolism 97 E1524-E1531. (doi:10.1210/jc.2012-1427)

Kwintkiewicz J, Nishi Y, Yanase T \& Giudice LC 2010 Peroxisome proliferator-activated receptor-gamma mediates bisphenol A inhibition of FSH-stimulated IGF-1, aromatase, and estradiol in human granulosa cells. Environmental Health Perspectives 118 400-406. (doi:10.1289/ehp. 0901161)

Lambert A, Harris SD, Knaggs P \& Robertson WR 2000 Improved FSH sensitisation and aromatase assay in human granulosa-lutein cells.
Molecular Human Reproduction 6 677-680. (doi:10.1093/molehr/ 6.8.677)

Langhout DJ, Spicer LJ \& Geisert RD 1991 Development of a culture system for bovine granulosa cells: effects of growth hormone, estradiol, and gonadotropins on cell proliferation, steroidogenesis, and protein synthesis. Journal of Animal Science 69 3321-3334.

Laven JS \& Fauser BC 2006 What role of estrogens in ovarian stimulation. Maturitas 54 356-362. (doi:10.1016/j.maturitas.2006.04.022)

Luborsky JL, Thiruppathi P, Rivnay B, Roussev R, Coulam C \& Radwanska E 2002 Evidence for different aetiologies of low estradiol response to FSH: age-related accelerated luteinization of follicles or presence of ovarian autoantibodies. Human Reproduction 17 2641-2649. (doi:10.1093/ humrep/17.10.2641)

Matsuda F, Inoue N, Manabe N \& Ohkura S 2012 Follicular growth and atresia in mammalian ovaries: regulation by survival and death of granulosa cells. Journal of Reproduction and Development 58 44-50. (doi:10.1262/jrd.2011-012)

McReynolds S, Dzieciatkowska M, McCallie BR, Mitchell SD, Stevens J, Hansen K, Schoolcraft WB \& Katz-Jaffe MG 2012 Impact of maternal aging on the molecular signature of human cumulus cells. Fertility and Sterility 98 1574-1580e5. (doi:10.1016/j.fertnstert.2012.08.012)

Mehlmann LM 2005 Stops and starts in mammalian oocytes: recent advances in understanding the regulation of meiotic arrest and oocyte maturation. Reproduction 130 791-799. (doi:10.1530/rep.1.00793)

Murphy BD 2000 Models of luteinization. Biology of Reproduction 63 2-11. (doi:10.1095/biolreprod63.1.2)

Nasseri A \& Grifo JA 1998 Genetics, age, and infertility. Maturitas 30 189-192. (doi:10.1016/S0378-5122(98)00073-5)

Natraj U \& Richards JS 1993 Hormonal regulation, localization, and functional activity of the progesterone receptor in granulosa cells of rat preovulatory follicles. Endocrinology 133 761-769. (doi:10.1210/endo. 133.2.8344215)

Navot D, Bergh PA, Williams MA, Garrisi GJ, Guzman I, Sandler B \& Grunfeld L 1991 Poor oocyte quality rather than implantation failure as a cause of age-related decline in female fertility. Lancet 337 1375-1377. (doi:10.1016/0140-6736(91)93060-M)

Nimz M, Spitschak M, Schneider F, Furbass R \& Vanselow J 2009 Down-regulation of genes encoding steroidogenic enzymes and hormone receptors in late preovulatory follicles of the cow coincides with an accumulation of intrafollicular steroids. Domestic Animal Endocrinology 37 45-54. (doi:10.1016/j.domaniend. 2009.02.002)

van Noord-Zaadstra BM, Looman CW, Alsbach H, Habbema JD, te Velde ER \& Karbaat J 1991 Delaying childbearing: effect of age on fecundity and outcome of pregnancy. BMJ 302 1361-1365. (doi:10.1136/bmj.302. 6789.1361)

Oonk RB, Krasnow JS, Beattie WG \& Richards JS 1989 Cyclic AMPdependent and -independent regulation of cholesterol side chain cleavage cytochrome P-450 (P-450scc) in rat ovarian granulosa cells and corpora lutea. cDNA and deduced amino acid sequence of rat P-450scc. Journal of Biological Chemistry 264 21934-21942.

Orisaka M, Mizutani T, Tajima K, Orisaka S, Shukunami K, Miyamoto K \& Kotsuji F 2006 Effects of ovarian theca cells on granulosa cell differentiation during gonadotropin-independent follicular growth in cattle. Molecular Reproduction and Development 73 737-744. (doi:10.1002/mrd.20246)

Oury F, Faucher C, Rives I, Bensaid M, Bouche G \& Darbon JM 1992 Regulation of cyclic adenosine $3^{\prime}, 5^{\prime}$-monophosphate-dependent protein kinase activity and regulatory subunit RII $\beta$ content by basic fibroblast growth factor (bFGF) during granulosa cell differentiation: possible implication of protein kinase C in bFGF action. Biology of Reproduction 47 202-212. (doi:10.1095/biolreprod47.2.202)

Out HJ, Braat DD, Lintsen BM, Gurgan T, Bukulmez O, Gokmen O, Keles G, Caballero P, Gonzalez JM, Fabregues F et al. 2000 Increasing the daily dose of recombinant follicle stimulating hormone (Puregon) does not compensate for the age-related decline in retrievable oocytes after http://joe.endocrinology-journals.org

DOI: $10.1530 / \mathrm{JOE}-15-0246$
(C) 2015 Society for Endocrinology Printed in Great Britain 
ovarian stimulation. Human Reproduction 15 29-35. (doi:10.1093/ humrep/15.1.29)

Ozcakir HT, Levi R, Tavmergen E \& Goker EN 2004 Premature luteinization defined as progesterone estradiol ratio $>1$ on hCG administration day seems to adversely affect clinical outcome in long gonadotropinreleasing hormone agonist cycles. Journal of Obstetrics and Gynaecology Research 30 100-104. (doi:10.1111/j.1447-0756.2003.00166.x)

Perreault SD, Barbee RR \& Slott VL 1988 Importance of glutathione in the acquisition and maintenance of sperm nuclear decondensing activity in maturing hamster oocytes. Developmental Biology 125 181-186. (doi:10.1016/0012-1606(88)90070-X)

Rao MC, Midgley AR Jr \& Richards JS 1978 Hormonal regulation of ovarian cellular proliferation. Cell 14 71-78. (doi:10.1016/0092-8674 (78)90302-1)

Rouillier P, Matton P, Dufour M, Sirard MA \& Guilbault LA 1998 Steroid production, cell proliferation, and apoptosis in cultured bovine antral and mural granulosa cells: development of an in vitro model to study estradiol production. Molecular Reproduction and Development 50 170-177. (doi:10.1002/(SICI)1098-2795(199806)50:2\%3C;170::AIDMRD7\%3E;3.0.CO;2-H)

Sadraie SH, Saito H, Kaneko T, Saito T \& Hiroi M 2000 Effects of aging on ovarian fecundity in terms of the incidence of apoptotic granulosa cells. Journal of Assisted Reproduction and Genetics 17 168-173. (doi:10.1023/ A:1009422323306)

Seifer DB, Charland C, Berlinsky D, Penzias AS, Haning RV Jr, Naftolin F \& Barker BE 1993 Proliferative index of human luteinized granulosa cells varies as a function of ovarian reserve. American Journal of Obstetrics and Gynecology 169 1531-1535. (doi:10.1016/0002-9378(93)90430-Q)

Seifer DB, Gardiner AC, Ferreira KA \& Peluso JJ 1996 Apoptosis as a function of ovarian reserve in women undergoing in vitro fertilization. Fertility and Sterility 66 593-598.

Seifer DB, DeJesus V \& Hubbard K 2002 Mitochondrial deletions in luteinized granulosa cells as a function of age in women undergoing in vitro fertilization. Fertility and Sterility 78 1046-1048. (doi:10.1016/ S0015-0282(02)04214-0)

Sen A \& Hammes SR 2010 Granulosa cell-specific androgen receptors are critical regulators of ovarian development and function. Molecular Endocrinology 24 1393-1403. (doi:10.1210/me.2010-0006)

Senbon S, Hirao Y \& Miyano T 2003 Interactions between the oocyte and surrounding somatic cells in follicular development: lessons from in vitro culture. Journal of Reproduction and Development 49 259-269. (doi:10.1262/jrd.49.259)

Shuhaibar LC, Egbert JR, Norris RP, Lampe PD, Nikolaev VO, Thunemann M, Wen L, Feil R \& Jaffe LA 2015 Intercellular signaling via cyclic GMP diffusion through gap junctions restarts meiosis in mouse ovarian follicles. PNAS 112 5527-5532. (doi:10.1073/pnas.1423598112)

Skiadas CC, Duan S, Correll M, Rubio R, Karaca N, Ginsburg ES, Quackenbush J \& Racowsky C 2012 Ovarian reserve status in young women is associated with altered gene expression in membrana granulosa cells. Molecular Human Reproduction 18 362-371. (doi:10.1093/molehr/gas008)

Slovis BH \& Check JH 2013 Younger women with diminished oocyte reserve are not more prone to meiosis errors leading to spontaneous abortion than their age peers with normal oocyte reserve. Clinical and Experimental Obstetrics \& Gynecology 40 29-32.

Tapanainen J, Leinonen PJ, Tapanainen P, Yamamoto M \& Jaffe RB 1987 Regulation of human granulosa-luteal cell progesterone production and proliferation by gonadotropins and growth factors. Fertility and Sterility 48 576-580.

Tatone C 2008 Oocyte senescence: a firm link to age-related female subfertility. Gynecological Endocrinology 24 59-63. (doi:10.1080/ $09513590701733504)$

Tatone C, Amicarelli F, Carbone MC, Monteleone P, Caserta D, Marci R, Artini PG, Piomboni P \& Focarelli R 2008 Cellular and molecular aspects of ovarian follicle ageing. Human Reproduction Update $\mathbf{1 4}$ 131-142. (doi:10.1093/humupd/dmm048)

Tsuji T, Kiyosu C, Akiyama K \& Kunieda T 2012 CNP/NPR2 signaling maintains oocyte meiotic arrest in early antral follicles and is suppressed by EGFR-mediated signaling in preovulatory follicles. Molecular Reproduction and Development 79 795-802. (doi:10.1002/mrd. 22114)

Webb RJ, Marshall F, Swann K \& Carroll J 2002 Follicle-stimulating hormone induces a gap junction-dependent dynamic change in [cAMP] and protein kinase a in mammalian oocytes. Developmental Biology 246 441-454. (doi:10.1006/dbio.2002.0630)

Weeg N, Shalom-Paz E \& Wiser A 2012 Age and infertility: the clinical point of view. Minerva Ginecologica 64 477-483.

Wigglesworth K, Lee KB, O’Brien MJ, Peng J, Matzuk MM \& Eppig JJ 2013 Bidirectional communication between oocytes and ovarian follicular somatic cells is required for meiotic arrest of mammalian oocytes. PNAS 110 E3723-E3729. (doi:10.1073/pnas.1314829110)

Ye Y, Kawamura K, Sasaki M, Kawamura N, Groenen P, Gelpke MD, Rauch R, Hsueh AJ \& Tanaka T 2009 Kit ligand promotes first polar body extrusion of mouse preovulatory oocytes. Reproductive Biology and Endocrinology 7 26. (doi:10.1186/1477-7827-7-26)

Younis JS 2012 Ovarian aging and implications for fertility female health. Minerva Endocrinologica 37 41-57.

Younis JS, Haddad S, Matilsky M \& Ben-Ami M 1998 Premature luteinization: could it be an early manifestation of low ovarian reserve? Fertility and Sterility 69 461-465. (doi:10.1016/S0015-0282(97)00561-X)

Younis JS, Matilsky M, Radin O \& Ben-Ami M 2001 Increased progesterone/estradiol ratio in the late follicular phase could be related to low ovarian reserve in in vitro fertilization-embryo transfer cycles with a long gonadotropin-releasing hormone agonist. Fertility and Sterility $\mathbf{7 6}$ 294-299. (doi:10.1016/S0015-0282(01)01918-5)

Zhang M, Su YQ, Sugiura K, Xia G \& Eppig JJ 2010 Granulosa cell ligand NPPC and its receptor NPR2 maintain meiotic arrest in mouse oocytes. Science 330 366-369. (doi:10.1126/science.1193573)

Zhou P, Wu YG, Li Q, Lan GC, Wang G, Gao D \& Tan JH 2008 The interactions between cysteamine, cystine and cumulus cells increase the intracellular glutathione level and developmental capacity of goat cumulus-denuded oocytes. Reproduction 135 605-611. (doi:10.1530/ REP-08-0003)

Zhou P, Wu YG, Wei DL, Li Q, Wang G, Zhang J, Luo MJ \& Tan JH 2010 Mouse cumulus-denuded oocytes restore developmental capacity completely when matured with optimal supplementation of cysteamine, cystine, and cumulus cells. Biology of Reproduction 82 759-768. (doi:10.1095/biolreprod.109.082206)

Zhou P, Baumgarten SC, Wu Y, Bennett J, Winston N, Hirshfeld-Cytron J \& Stocco C 2013 IGF-I signaling is essential for FSH stimulation of AKT and steroidogenic genes in granulosa cells. Molecular Endocrinology 27 511-523. (doi:10.1210/me.2012-1307)

Received in final form 29 June 2015

Accepted 8 July 2015 http://joe.endocrinology-journals.org

DOI: $10.1530 / J O E-15-0246$
(C) 2015 Society for Endocrinology Printed in Great Britain
Published by Bioscientifica Ltd 